\title{
RECREATIONAL CARRYING CAPACITY ON SMALL MEDITERRANEAN ISLANDS
}

\author{
María José Viñals ${ }^{1}$ \\ Mario Planelles \\ Pau Alonso-Monasterio \\ Maryland Morant \\ Universitat Politècnica de València
}

\begin{abstract}
Small islands are areas of high ecological and heritage value as well as tourist attractions for a variety of visitors. Therefore, strict regulation of visits is necessary to minimize the impact of visitors. Studies on Recreational Carrying Capacity are effective tools to manage public use. In the case of small islands, these tools must include restrictive corrective factors related to both the ecological and morphological characteristics of the islands and the psychological comfort of the visitors.
\end{abstract}

Keywords: Recreational Carrying Capacity; Small Islands; Public Use; Tourism.

La capacidad de carga recreativa en pequeñas islas del Mediterráneo

\section{RESUMEN}

Las pequeñas islas son espacios de alto valor ecológico y patrimonial a la vez que focos de atracción turística para visitantes de perfil variado, lo que hace necesaria una estricta regulación de las visitas que minimice los impactos derivados de éstas. Los estudios de Capacidad de Carga Recreativa constituyen efectivas herramientas para la gestión del uso recreativo que, en el caso de pequeñas islas, deben incluir parámetros correctores restrictivos relacionados, por un lado, con las especiales características ecológicas y morfológicas y, por otro, con aspectos de confort psicológico de los visitantes.

Palabras clave: Capacidad de Carga Recreativa; Pequeñas Islas; Uso Público; Turismo.

Received: 20 April 1015

Returned for revision: 16 June 2015

Accepted: 12 September 2015

1 Departamento de Ingeniería Cartográfica. Universitat Politècnica de València. Camino de Vera, s/n. 46022 VALENCIA (España).E-mail: mvinals@upv.es 


\section{INTRODUCTION}

Islands represent a special case of tourist destinations. These areas traditionally attract tourism, but their specific characteristics make these places fragile and vulnerable to human impacts. Therefore, islands, especially small islands, require special consideration when tourism-enhancing processes are carried out.

Islands sensu stricto are ecosystems characterized by varying closure depending on dispersion vectors and on the distance to other lands, as the sea is an uncrossable barrier for many terrestrial species. Isolation can generate qualitative differences in the ecological structure. As a result, island biological communities are structured with few elements; they are usually species-poor ecosystems, and this feature is more noticeable the greater the distance from the mainland and the smaller the island. Moreover, this small size constrains the trophic structure of terrestrial communities, resulting in a lack of higher trophic levels such as large herbivores or carnivores. Because of these ecological peculiarities, island natural communities also become permeable to intrusion by species introduced by man (Whittaker and Fernández-Palacios, 2007).

Geologically, the origin of small islands can be very varied: volcanic islands have abrupt morphologies, sedimentary islands are generally rocky fragments of mountain ranges, reef islands are built of corals and arise in warm seas, and other islands are formed by emerging sandbars in shallow coastal areas. There are also river islands and those located in lakes and wetlands, which arise from materials deposited in these aquatic systems. All have particular morphological characteristics not usually found in other terrestrial ecosystems.

However, isolation combined with time, geological history, and environmental compartmentalization of the island lead to the generation of local endemic species. This fact is the most distinctive island phenomenon, especially on volcanic islands. Again, distance from the mainland, island size, and age favour a unique but fragile biodiversity (Machado, 2010).

The scientific community recognizes these islands, with their peculiar features, as magnificent living laboratories, where studies on ecological processes arising from their insular nature can be carried out. However, in recent decades, in addition to ecological aspects, special attention has been paid to social issues and to the natural and cultural heritage of islands as a result of new sustainable approaches focused on their conservation because these areas are more vulnerable to impacts than similar continental ecosystems. As Mata (2006) states, small islands have limited natural, economic and social carrying capacities. Island ecosystems, or each island as a whole ecosystem at a given scale, are both valuable and vulnerable. The limited natural and human resources of islands make them particularly fragile. Activities that involve high consumptions of the capital resources and land risk irreversibly disrupt islands' socio-ecological balance and threaten their natural and cultural heritage.

From the tourism point of view, the intrinsic attributes of islands make them highly attractive to tourists interested in enjoying exclusive beaches and to adventure tourists, as observed in tourism advertisements presenting these islands as paradisiacal. They are also a source of interest to ecotourists who are attracted by the natural attributes of 
these ecosystems. Recently, there have been significant flows of active tourists interested in water activities, especially diving and recreational boating. Tourism has resulted in an increased pressure on islands and their surrounding waters, sometimes leading to congestion, especially by recreational boats moored near islands. For these reasons, the authorities responsible for island management must create specific planning and management tools to regulate tourism and avoid impacts on their resources.

For small islands, this situation is even more critical. In this context, a «small island» or «islet» must be defined. After analysing definitions given by different authors, Bowett (1979) concluded that small islands or islets are those that have surface areas of approximately $1 \mathrm{~km}^{2}$. Islands of this size are called «islets» by Westra et al. (2015), emphasizing that they are not necessarily rocky blocks. These small islands are usually uninhabited and are highly vulnerable to human impacts, but their geomorphology, wilderness and integrity as well as their adjacent seabed make them very attractive to tourists, as previously mentioned. For these reasons, many of these islands are protected by highly restrictive legal constructs (integral reserves, nature reserves, etc.).

In the Western Mediterranean Sea, many small islands have these characteristics, including the Medes Islands in Girona, Spain $\left(0.21 \mathrm{~km}^{2}\right)$, the Columbretes Islands in Castellón $\left(0.19 \mathrm{~km}^{2}\right)$, Tabarca Island in Alicante $\left(0.3 \mathrm{~km}^{2}\right)$, S'Espalmador Island in the Balearic Islands $\left(1.38 \mathrm{~km}^{2}\right)$, and Alborán Island in Almería $\left(0.07 \mathrm{~km}^{2}\right)$. Other islands sharing the same characteristics are the Lavezzi Islands in France $\left(1.91 \mathrm{~km}^{2}\right)$; the Italian islands of Gallinara $\left(0.11 \mathrm{~km}^{2}\right)$ and Budelli $\left(1.6 \mathrm{~km}^{2}\right)$, the Island of Serpentara in Sardinia $\left(0.3 \mathrm{~km}^{2}\right)$; Chikly Island in Tunisia $\left(0,035 \mathrm{~km}^{2}\right)$ and the Habibbas Archipelago in Algeria $\left(0.4 \mathrm{~km}^{2}\right)$. According to Conservatoire du Littoral - PIM Initiative (2015), only 35 out of the 15,000 small Mediterranean islands and islets are officially managed, and many of them have never been studied.

Many of these small islands have experienced some human use, although none of these uses has been ongoing. Past uses have included the construction of castles and defensive fortresses for military purposes, especially on islands near the coastline, and other purposes related to seamanship, such as quarantine stations (lazzaretti) and, more recently, lighthouses. The small island of Lazzaretto Vecchio in the Venetian Lagoon (Italy) houses the first quarantine station, which was created by the Reppubblica Serenissima in 1423.

With the decline in these uses, in most cases, these buildings and islands were abandoned. It was not until the late 20th century that their legal protection and the restoration and enhancement of their natural and cultural heritage were revived. Thus, these small islands were long unadvertised in tourist brochures. However, growing pressure from tourists seeking unique experiences has increasingly led these islands to be promoted as destinations worldwide. The smallest islands are not the most attractive to tourists because of the difficulties of access, the lack of infrastructure and facilities, and, frequently, the limited availability of fresh water. Additionally, some are privately owned. Nevertheless, islands near the coastline have been experiencing one-day visitor flows where environmental laws and regulations permit visitation, basic facilities exist (piers, paths, etc.), and natural and/or cultural attractions can be visited (lighthouse, fortification, barracks, etc.). These visitors sometimes arrive in their own boats. 
The Recreational Carrying Capacity (RecCC) is a useful management tool for establishing the limits of the recreational use of these ecosystems and their resources and providing a quality experience for visitors. This concept is sometimes confused with the Tourism Carrying Capacity, which refers to the accommodation and restauration offerings of a destination (van der Borg, 2001). The latter concept is not applicable to small islands, which lack such infrastructure.

\section{OBJECTIVE AND METHOD}

This paper aims to identify and analyse the key factors that determine the Recreational Carrying Capacity of small islands. To verify its effectiveness, these factors were included in case studies of Mediterranean islands: the Columbretes Islands in Castellón (Spain), Chikly Island in Tunisia and S'Espalmador Island in the Balearic Islands (Spain).

This study exploits the authors' experience in research on the determination of recreational carrying capacity in archaeological sites, monuments, areas of public use in protected areas, etc. (Morant and Viñals, 2010; Viñals et al., 2013). Additionally, a spatial analysis and an analysis of the intrinsic attributes of small islands were carried out to identify key factors defining the special characteristics of small islands whose disruption would cause irreversible changes.

To this end, a literature review was conducted to learn how this issue was addressed in previous works. Studies on the recreational carrying capacity of islands are common in the literature, but most were performed on larger islands, such as tropical islands of the Caribbean (Jackson, 1986), Menorca in the Balearic Islands, Spain (Roig Munar, 2003), Cozumel in Mexico (Segrado et al., 2008), and Lanzarote in the Canary Islands, Spain (Cabildo de Lanzarote, Island Council of Lanzarote, 2013). Some studies of recreational carrying capacities assess specific recreational activities, such as diving in Cocos Island, Costa Rica (Chasqui, 2008) and Roqueta Island in Acapulco, Mexico (Velasco, 2013) or surfing in small Indo-Pacific islands (Bukley, 2002).

Studies on recreational carrying capacity related to protected areas on small islands are scarcer because these places do not usually promote their use for recreational activities. However, the work of Amador et al. (1996), who examined designated areas for public use on the larger islands of Galapagos National Park (Ecuador), should be emphasized. Genchi and Rosell (2010) analysed a nature reserve on the small island in the Puan Lagoon (Argentina), Figueroa and Rotarou (2013) studied Rapa Nui National Park on Easter Island (Chile), and Tellado et al. (2014) determined the recreational carrying capacity of the Atlantic Islands of Galicia National Park (Spain), including the Cies Archipelago.

\section{KEY FACTORS IN THE ANALYSIS OF THE CARRYING CAPACITY OF SMALL ISLANDS}

Studies aiming to determine carrying capacity are generally difficult to conduct, as the contexts are very diverse. Therefore, if the study is to yield useful and actionable outcomes, many specific characteristics to each place must be considered, especially for small islands. 
There is an extensive methodological literature regarding this type of management tool. In the initial phase, studies were largely based on mathematical formulae and correction coefficients that are difficult to apply to all cases. Subsequent studies have focused on the «limits of acceptable change» (Stankey et al., 1985), considering the strengths/weaknesses or reversibility/irreversibility of impacts to establish the limits of use of these ecosystems. These studies are currently also approached from a logical reasoning and systemic perspective (Cole and Carlson, 2010), which is our approach.

Studies on recreational carrying capacity are usually based on the analysis of the physical conditions of the site (types and dimensions of the available space, and natural, cultural and scenic resources) to determine its fragility $v s$. resistance to recreational impacts, as well as the type of activity to be developed. Here, the analysis of potential impacts includes quantitative and qualitative aspects in relation to users and facilities. Therefore, some limiting spatial and ecological factors are identified in order to implement the necessary measures to ensure the conservation of the values and functions of these resources. However, the factors related to the physical and psychological comfort of visitors must also be considered to guarantee a satisfactory recreational experience.

The morphology of small islands implies restricting factors, e.g., islands of rocky or volcanic origin have slopes and sometimes cliffs that hinder access and passage and may pose real physical risk to visitors, whereas flat sedimentary islands devoid of arboreal vegetation have high landscape fragility, and even the presence of visitors has a visual impact. For obvious reasons, the space for recreational use on small islands $\left(\sim 1 \mathrm{~km}^{2}\right)$ is minimal. In many cases, the available space is also reduced to conserve biodiversity, which results in legal restrictions due to protective measures. Thus, many of these small islands have very restrictive legal statuses for protection due to their fragility and/or to the existence of rare, endemic and/or endangered flora and fauna species that require the preservation of sufficient land to ensure their long-term viability.

Moreover, biodiversity of small islands is generally low, however, the species on these islands are considered target species in conservation priorities, even when the species have shared stocks with mainland populations. In many cases, the isolation of island populations has favoured speciation into endemic taxa (species and/or subspecies), which because of their limited range, are also usually threatened. In addition, insular endemic species in restricted areas are often highly adapted to particular environmental conditions and may lack the adaptive flexibility required to cope with drastic changes in these conditions.

The limited space is a fundamental aspect of small islands, especially those with endemic or endangered species. In these cases, one useful concept is the Minimum Viable Population (MVP) of a given specie in a specific habitat, which is defined as «the smallest isolated population having a 99\% chance of remaining extant for 1000 years despite the foreseeable effects of demographic, environmental and genetic stochasticity, and natural catastrophes» (Shaffer, 1981). Another concept is the Minimum Dynamic Area (MDA), which is defined as the amount of suitable habitat available to maintain an MVP (Primack and Ross, 2002). MVP and MDA should be considered when managing recreational activities and determining the recreational carrying capacity.

The fragility of the ecosystem and thus its potential for recreational use will be mediated by, among other factors, the number of endemic species, the stock of specimens 
of each endemic species, and the location of these populations across the potential range, as populations within the limits of their range are the most vulnerable.

The types of species must also be taken into account, especially with regard to their phenology, mobility and dispersal capability. The circadian rhythms of the more interesting or representative species must influence and may be influenced by the development of recreational activities in these environments. Thus, for example, if certain birds are an attraction for visitors, their nesting or breeding periods must be taken into account, as the presence of humans may adversely affect these processes, and these activities should be restricted during these times.

Terrestrial species often have limited flight or dispersal capability on small islands, so the existence of interesting species of this type should also be considered a limiting factor when allowing the development of certain activities.

The size of the island and the configuration of the space in relation to habitat fragmentation and connectivity must also be considered. The smaller the ecosystem, the more fragile it is. Fragmentation of habitats is one of the factors that most affect their functionality, as it isolates habitats and thus weakens their individual functions. For all of these reasons, the entirety of small islands is often protected.

The most significant types of potential impacts of visitors on small islands are related to soil compaction and/or erosion on paths and surrounding areas as a result of repeated trampling. Other impacts are: loss of vegetation cover, especially shrubs and herbs near trails, wildlife disturbance, possible introduction of exotic and/or predator species that may be invasive in the absence of competitors, and waste accumulation if the visitors' behaviour is inappropriate. These changes could alter habitats and result in stress to species whose capacity to move is very limited.

Social limiting factors associated with visitors are linked to the quality of the recreational experience. They are established through the analysis of the factors related to the physical and psychological comfort of visitors. Viñals et al. (2014) examined more than 2,700 surveys administered to visitors of protected areas to establish a set of factors determining the comfort of the visitors. These factors include aspects of physical and physiological requirements related to the environment as well as to facilities and services available. Their analysis includes the consideration that individuals have very different needs, motivations and expectations, depending on their personality traits.

Bioclimatic and safety factors are especially important in terms of physical and physiological requirements. On small islands in the Mediterranean Sea, climate is a key factor of comfort because the large number of sunny days, low rainfall and generally low risk of climate catastrophes positively affect the enjoyment of tourists (Gómez Martín, 1999). Only wind, especially above $30 \mathrm{~km} / \mathrm{h}$, could cause discomfort. Indeed, as noted by Hernández (1990), these winds can cause psychological distress, especially in the winter, hindering open sea crossings. However, moderate breezes can mitigate high temperatures in summer (Martínez Ibarra, 2006), especially as island winds have a multi-directional component due to the existence of coastline all around the island.

On the other hand, visitors can feel insecure for a variety of reasons, including natural hazards, lack or poor state of facilities and installations, lack of information and signage system, lack of emergency plans, etc. However, feelings of security/insecurity 
are also linked to people's risk perception (Lepp and Gibsol, 2003; Zuckerman, 2007), which depends on individual personality traits, gender, previous experience, etc. On small islands, risk perception may be increased by distance from the mainland and a lack of regular communication. If public use activities are to be carried out, emergency and evacuation plans must be a priority, and visitors should be informed in that regard.

The type of environment also influences visitors' perceptions. Small islands are open spaces without barriers, although the sea could be perceived as a barrier by some visitors. Another factor affecting the quality of the experience is a high use level (saturation and congestion). In the scientific literature on tourism, many studies have focused on congestion (Manning, 1999; Morgan and Lok, 2000; Vaske and Donnelly, 2002; World Tourism Organization, 2004). Congestion tends to generate dissatisfaction with the recreational experience because of the psychological discomfort of visitors who seek to enjoy nature in solitude. However, other visitors may negatively perceive unfrequented spaces, as more agoraphobic individuals can find that small islands trigger feelings of insecurity and danger (Davidson, 2003; Bernarda and Lewis, 2003; Van Tilburg and Vingerhoets, 2005; Vivas, 2009).

Facilities and services are not a key determinant of the tourist experience on small islands because visitors interested in visiting them are aware of their limitations (lack of fresh water, energy, toilets, etc.) and because they seek authentic experiences. Thus, in most cases, paths and simple signs are enough. The necessary facilities are usually located on the mainland, near embarkation points. Nevertheless, these islands usually offer guidance services (sometimes assumed by the coast guard) as the visits are often organized, scheduled and guided.

Some of the main characteristics influencing visitors' attitudes and behaviour during their visit to these areas have already been outlined. Thus, it should be remembered that the motivations for visiting small islands are primarily concerned with adventure, the search for new experiences, a «escape» spirit, as defined by Luo and Deng (2008) and Line and Costen (2011), and the feeling of exclusivity in knowing and enjoying unique places that are not visited on a massive scale.

For studies on recreational carrying capacity, these personality traits translate into a need for more personal space than usual, as described by research on proxemics. Thus, social distance (the comfortable distance separating people who do not know each other well), established by Hall (1966) at 120-360 cm, would increase to the maximum distance of at least in $360 \mathrm{~cm}$ or even to the range of a public distance $(>360 \mathrm{~cm}$ ) for visitors seeking solitude.

As seen from the studies conducted by Manning et al. (1996) and Manning (2011), other indicators of a quality experience are related to the number of people in one place at one time (PAOT) or the number of people per view (PPV). The latter is important on small islands because of their visual vulnerability, especially on flat islands. Additionally, panoramic sea views must also be considered as a landscape resource. The presence of many boats near an island sometimes has a negative visual impact. On the other hand, Stankey and McCool (1984) examined the impact of the number of encounters with other groups or people along a route. On a small island, more than one encounter may cause psycological discomfort to the type of visitor described above. 


\section{CASE STUDIES}

\subsection{Columbretes Islands}

The archipelago of the Columbretes Islands consists of 24 islands and is located in the Mediterranean Sea $\left(39^{\circ} 51^{\prime}-39^{\circ} 55^{\prime} \mathrm{N}\right.$ and $\left.0^{\circ} 40^{\prime}-0^{\circ} 42^{\prime} \mathrm{E}\right), 56 \mathrm{~km}$ away from Cabo de Oropesa. It belongs to the municipality of Castellón de la Plana (Spain) and covers 19 ha, with l'Illa Grossa (14 ha) being the largest island of the archipelago (fig. 1).

\section{Figure 1 \\ COLUMBRETES ISLANDS. IN THE BACKGROUND, L'ILLA GROSSA, WHERE THE LIGHTHOUSE IS LOCATED}



After they were used as a bombing range for aviation, the Valencian Regional Government (Consell de la Generalitat Valenciana) declared the Columbretes Islands a Natural Park by Decree 15/1988 of 25 January. Law 11/1994 of 27 December reclassified this area as a Nature Reserve and approved the Master Plan for Use and Management (Plan Rector de Uso y Gestión - PRUG). Currently, the park includes two Botanical MicroReserves and two Integral Reserves (the islets of Carallot and l'Illa Grossa). This park was declared a Special Protection Area (SPA) for birds under the EU Birds Directive and a Site of Community Importance (SCI) under the EU Habitats Directive.

By an Order of 19 April 1990, the Spanish Ministry of Agriculture, Fisheries and Food created a Marine Reserve of 4,400 ha, which was declared a Specially Protected Area of Mediterranean Importance (SPAMI) within the framework of the Barcelona Convention for the Protection of the Marine Environment and the Coastal Region of 
the Mediterranean. In 2014, by Ministerial Order AAA/2280/2014 of December 1, the inclusion of the marine space in the Natura 2000 list of Sites of Community Importance was also approved.

This archipelago is a group of islets and rocky blocks linked to ancient volcanoes (Pautot et al., 1973; Maufret et al., 1978) and associated with an active process of rifting from the lower Miocene. It represents a unique example of volcanism in the Valencian region.

From the climate point of view, these islands are characterized by low annual rainfall $(265 \mathrm{~mm})$ and an average temperature of $16.9^{\circ} \mathrm{C}$. Northerly winds are frequent and of short duration, and there are thermal breezes at noon. In winter in the channel that separates the islands from the coast, rough seas occur. They are caused by winds from the first quadrant (N, NE and E). The annual average insolation is 7.3 hours per day (Font Tullot, 1984).

All of these factors explain the xeromorphic structure of plants and low specific diversity of these islands (del Hoyo et al., 1992). However, 14 endemic species that are unique to the archipelago and to the Balearic Ibero-Levantine region have been recorded, of which 2 are plants (Lobularia marítima columbretensis and Medicago citrina, which is the largest woody shrub in the archipelago), and 12 are animals, including invertebrates (a Valencian endemic gastropod, 2 mites and 8 insects) and 1 vertebrate, the Columbretes lizard (Podarcis atrata). There are also a large number of colonial seabirds typical of the Valencian and Balearic coastal environments (del Hoyo et al., 1992), including the following nesting species: Audouin's gull (Larus audouinii), the storm petrel (Hydrobates pelagicus), Eleonora's falcon (Falco eleonorae) and Cory's shearwater (Calonectris diomedea), which has a breeding colony on the island with at least 55 couples according to coast guards information. The critically endangered Balearic shearwater (Puffinus mauretanicus) uses these waters as a feeding area (ERENA S.L., 2014). These islands also represent an important resting place for birds migrating between Europe and Africa. Snakes, whose abundance refers to the ancient Roman name of the archipelago (Colubraria), are now extinct.

Humans have been intermittently present on the islands since at least Roman times, as seen from the remains of shipwrecks in the seabeds adjacent to the islands (Pascual, 1975). From the 14th century to the early 19 th century, these islands were havens for pirates and North African corsairs who attacked the Spanish Mediterranean coasts. Subsequently, these small islands were frequented by smugglers. By the middle of the 19th century, a lighthouse and some barracks were built on l'Illa Grossa. Settlement involved burning vegetation to eradicate the numerous scorpions and snakes that inhabited the island. In the 1970s, the lighthouse was automated, and the island has since remained uninhabited.

Currently, Illa Grossa or Columbrete Grande is the only island that can be visited (fig. 2). It has a horseshoe-shape and opens eastward, as it is formed from an ancient crater. It is approximately 1,250 m long, and its topography recalls the back of a whale, with a maximum width $(220 \mathrm{~m})$ at Punta de Tramuntana, where the lighthouse is located at a high elevation $(84.65 \mathrm{~m})$.

Visits to observe the natural environment are allowed in the restricted area defined by the Master Plan for Use and Management (section 2, art. 25), which is the path that goes from Tofiño harbour to the lighthouse. The harbour is in the sheltered marine area inside 
the crater and has a staircase leading to a small pier measuring $59.40 \mathrm{~m}^{2}$. The linear path that runs along the inner slope of the crater, although very close to the water dividing line, is $548 \mathrm{~m}$ long, with an average width of $1.50 \mathrm{~m}$ (width that only allows for oneway movement) and an average gradient of approximately 5\%. In front of the barracks, a flattened area of $169 \mathrm{~m}^{2}$ (Llanada de las Casernas) is used as a panoramic viewpoint and interpretive station (fig. 2).

\section{Figure 2 \\ LOCATION OF EXISTING FACILITIES ON L'ILLA GROSSA, COLUMBRETES ISLANDS}

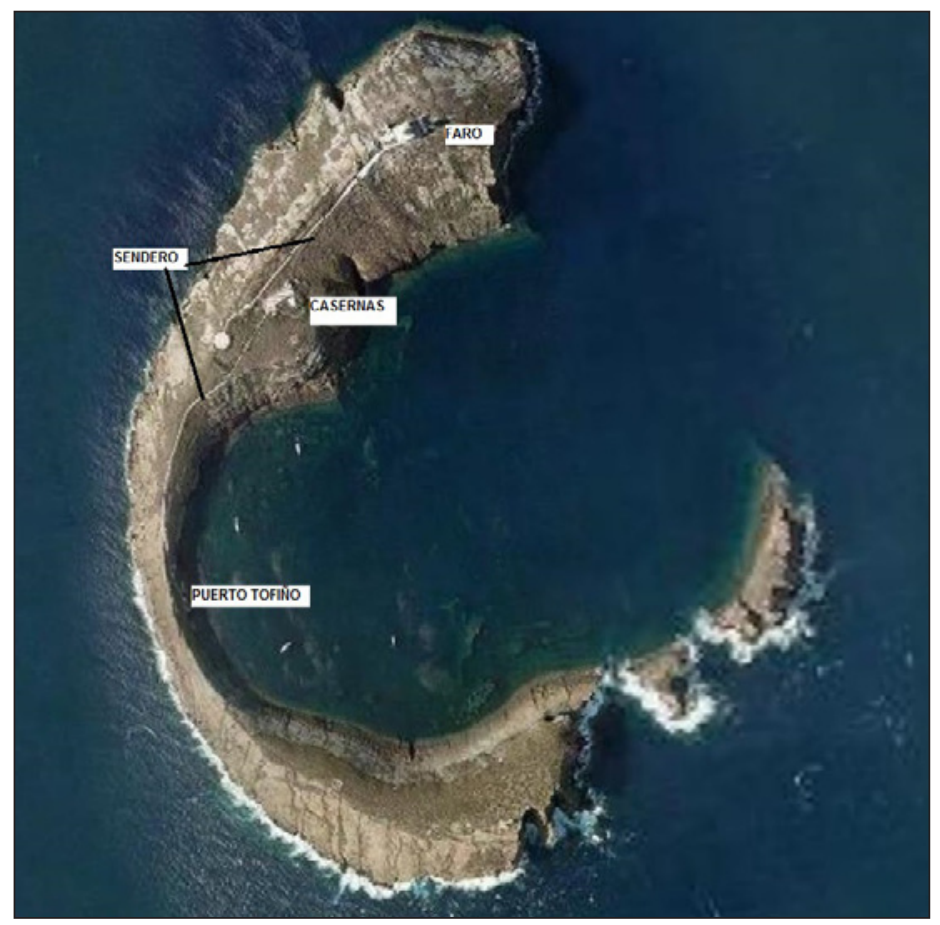

The lighthouse is an approximately square two-story building with a cylindrical tower. The ground floor houses a small visitor centre covering $46 \mathrm{~m}^{2}$. In addition, there are three mooring buoys in the bay for boats of up to $30 \mathrm{~m}$ in length. The use of anchors is prohibited.

Visits are regulated by the Master Plan for Use and Management in Art. 19, which states that «walking the path requires authorisation by the park director and this authorisation is subject to the limitations of the group size and of the daily quota of visitors, which must be set by him, with prior favourable approval from the Protection Board, following the criteria set by the seasonal vulnerability of the environment and depending on the nature and purpose of the visit... ...This natural space can only be visited in the period from two 
hours after sunrise to two hours before sunset, always in the presence of the park rangers... ...The park director is also authorized to partially or totally restrict visitor access to l'Illa Grossa, depending on the state of the faunal and floral communities».

The quota of visitors set by the Protection Board in 2005 was 69. In 2012, it was increased to 78 during working days (70 on motor launches and 30 on charter boats) and 120 during weekends and holidays in July and August. The possibility of unplanned tours was also considered.

Boat traffic is free in the waters surrounding the Columbretes Islands, but anchoring is controlled and not allowed in over 15 knots of wind. Disembarking requires authorization.

To determine and manage the carrying capacity of these islands, various factors must be considered. First, as mentioned previously, the special biogeographical characteristics of these islands are clearly apparent. Thus, their geological uniqueness, their importance as a resting area for a large number of birds migrating between Africa and Europe and as a breeding area for highly endangered species, the presence of endemic species, and the ecological value of their seabeds decisively limit public-use activities.

Another limiting factor is landscape fragility. The presence of humans is a visual intrusion that affects the quality of the viewshed because of the large number of elevated viewpoints from the pathway towards the rest of the island (fig. 3). This intrusion may cause psychological discomfort for visitors who, as previously mentioned, are characterized by the search for unique experiences and do not tolerate the presence of other visitors or encounters with other groups. Given the topographical characteristics and the lack of tall vegetation, it is impossible to «hide» the presence of visitors, as the degree of intervisibility is very high. However, the external visual fragility (i.e., that of the panoramic sea views) is low, as there is no saturation by boats (there is no heavy traffic of boats and the number of mooring buoys is low) that may negatively affect the seascape quality, and nor is there visual obstruction of the horizon as the observation points are elevated (except in Tofiño Harbour).

In this particular case, facilities and accessibility play a key role in the management of the recreational carrying capacity. Thus, the distance to the mainland and the sailing conditions limit access to the island. Therefore, crossing in winter is complex, and service by the shuttle boat is suspended, imposing a seasonal limitation on visits (April to September). For security and access reasons, shipping companies do not operate regularly for the rest of the year. However, the surveillance and maintenance service of the Reserve operates on the island throughout the year and can serve the public if necessary.

During the tourist season, access may also be limited by time available to visitors and the effort/reward perceived by visitors (Schramm, 1965; Ham, 1992; Trapp et al., 1994) because the journey (round-trip, approximately 5 hours) is twice as long as the activity. It must, however, be noted that during the peak season, occasional restrictions may also arise due to weather and sea conditions. In this occasion, as there is a maximum quota of daily visits, tourists may reach the island but not be authorized to land ${ }^{2}$. There is also an economic constraint: although the tour the islands is free, and that managers could not allow landing, the cost of the boat ticket amounts to at least 50 euros, depending on the type of boat hired.

2 http://www.agricultura.gva.es/web/pn-illes-columbretes/recomendaciones-para-la-visita 


\section{Figure 3}

VIEWSHEDS IN THE ILLA GROSSA, COLUMBRETES ISLANDS. THE EYE ICON REPRESENTS THE VIEWPOINTS OF THE LIGHTHOUSE AND TOFIÑO HARBOUR AND THE AREAS THAT ARE VISIBLE FROM THOSE VIEWPOINTS ARE HIGHLIGHTED

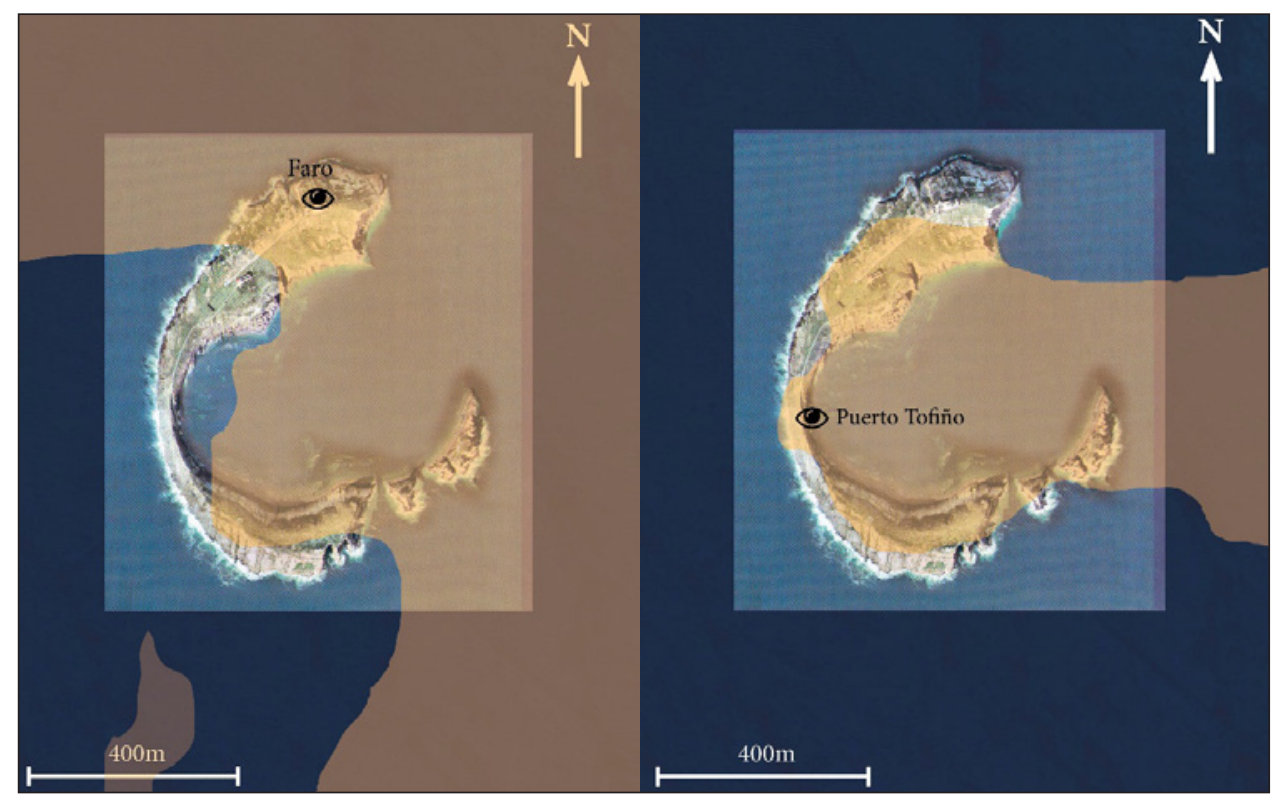

The organization of the visit allows a certain amount of leeway in the management of the carrying capacity. According to the Management Report of the Nature Reserve for 2012, the number of visitors to the island has stabilized at approximately 3,000 in recent years, with $84 \%$ of visitors arriving between June and September, especially in August $(40 \%)$. This figure may represent approximately less than 35 people a day in August.

The group size is set to approximately $20-25$ people, and the daily quota, as already mentioned, is 78 to 120 people. Larger boats can carry approximately 100 passengers. Thus, one such boat meets the daily limit. The island can receive two groups simultaneously if times and spaces are properly managed, but to avoid discomfort, they cannot share the same space. Thus, the historic lighthouse, which is a resistant and closed building is able to receive a group, as visitors show greater tolerance to sharing indoor spaces. Therefore, the $46 \mathrm{~m}^{2}$ of the lighthouse, it can welcome a group of $20-25$ people if a minimum interpersonal distance of $46 \mathrm{~cm}$ is established, according to the work on proxemics by Hall (1966). Hence, a group of this size may take up approximately $25 \mathrm{~m}^{2}$ and remain comfortable with enough space to move. Meanwhile, the other group may take the outside visit on the pathway without meeting any other group in the viewshed. To properly manage both groups considering the linear path, there must be an established sequence, i.e., the second group cannot start the visit until the first group is in the lighthouse, and the first 
group (from the lighthouse) will return once the second group reaches the lighthouse. The rest of the passengers may not take the tour to the island until the two previous groups are on board; they have to stay on board or do water activities in the bay.

\subsection{Chikly Island}

Chikly Island covers 3.5 hectares and is located in the Northern Lagoon of Tunis $\left(36^{\circ} 48^{\prime} \mathrm{N}\right.$ and $\left.10^{\circ} 13^{\prime} \mathrm{E}\right), 2 \mathrm{~km}$ away from the city of Tunis. It houses Fort Santiago, which was built by the Spanish Emperor Charles V in the 16th century (fig. 4).

\section{Figure 4 \\ CHIKLY ISLAND AND FORT SANTIAGO (TUNISIA)}

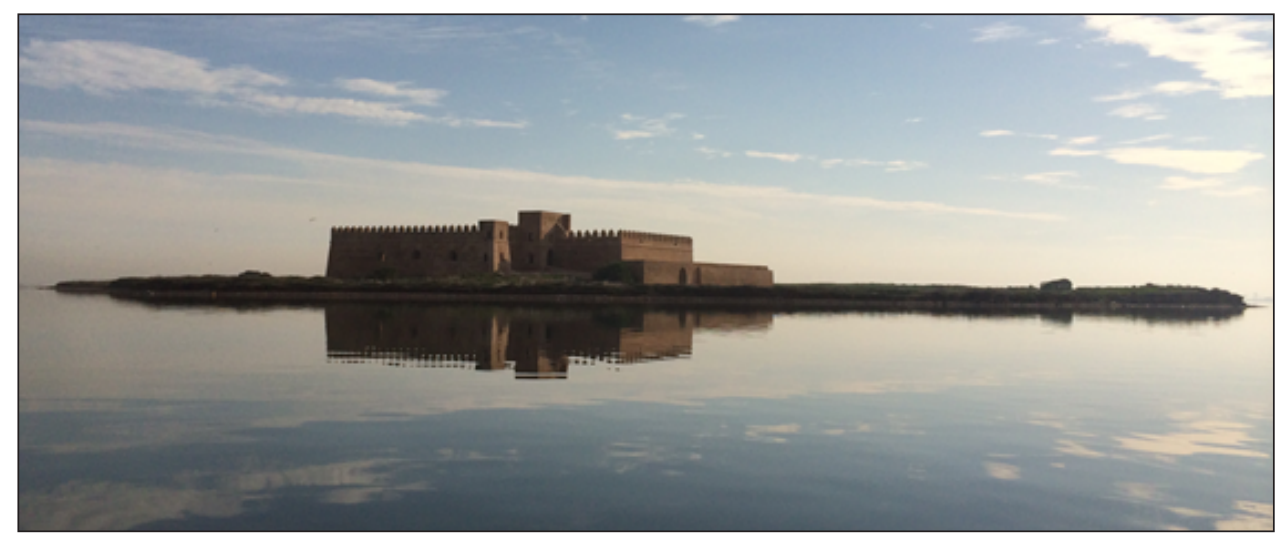

This land was declared a Nature Reserve in 1993 by the Government of the Republic of Tunisia, pursuant to Articles 218 and 219 of the Forestry Code. In 2005 and 2009, significant changes set new protection standards for these nature reserves and recommended drafting management plans. The Northern Lagoon of Tunis is considered an Important Bird Area (IBA) under the Birdlife International program. Since 2014, it has also been considered a Wetland of International Importance by the Ramsar Convention, in addition to being an IUCN category-IV Nature Reserve.

Tunis is characterized by a Mediterranean climate, with hot, dry summers and mild, relatively rainy winters, with an annual rainfall of $465.5 \mathrm{~mm}$, a minimum average temperature of $13.3^{\circ} \mathrm{C}$ and a maximum temperature of $23.5^{\circ} \mathrm{C}$, according to data from Meteofrance 3 . The prevailing winds come from the north and west with gusts at $83.5 \mathrm{~km} / \mathrm{h}$ (Banque Mondiale, 2011).

The island is almost flat, with an average height of $2 \mathrm{~m}$ above sea level, alternating with small natural centimetre elevations and mounds of drainage materials with small depressions.

3 www.meteofrance.com (Accessed on 8/1/2015) 
The sedimentary origin of the island is the result of the accumulation of silty-clayey material, peat, and dredged material that includes calcareous shells and fragments of pottery and bone. A narrow artificial dike (of $\pm 1.5 \mathrm{~m}$ wide and $8.2 \mathrm{~km}$ long) connects the island to the coastal area of La Goulette. Access is closed to the public and secured by the National Guard $24 \mathrm{~h}$ /day because archaeological remains have been looted from the island.

The vegetation is mainly composed of herbaceous halophytic bushes such as the succulent Chenopodiacae. Suaeda maritima is the only woody plant on the island; it is abundant in depressions that fill with water in winter. Other species include Halocnemum strobilaceum and Arthrocnemum indicum. Neffati et al. (1999) mentioned 4 plant species (Galactites mutabilis, Limoniun boitardii, Marrubium aschersonii and Silene barrattei), 2 subspecies (Hippocrepis minor subsp. brevipetala and Onopordon nervosum subsp. platylepis) and one endemic variety (Koeleria pubescens subsp. villosa var. doumeti).

Waterfowl gives the island its highest natural value, with 57 wintering species that take refuge on this island. It houses $6 \%$ of the wintering population of flamingos (Phoenicopterus roseus) from the Western Palaearctic region, with between 8,000 and 10,000 pairs. The wintering populations of cormorant (Phalacrocorax carbo), white spoonbill (Platalea leucorodia), stilt (Himantopus himantopus), pintail (Anas acuta) and shoveller (Anas clypeata) are also abundant. Other species form breeding colonies: the little egret (Egretta garzetta), as Chikly Island is one of the few places in Tunisia where they can nest, the yellow-legged gull (Larus michaelis), the shelduck (Tadorna tadorna) and the great crested grebe (Podiceps cristatus), among others.

Regarding the cultural heritage, the island is known for Fort Santiago, an outstanding 16th-century building covering $2,400 \mathrm{~m}^{2}$, with a rectangular floor plan, an inner courtyard and two towers of different height. After it was used for military purposes, it served as a quarantine facility from the 18th century until the middle of the 19th century. Then, it was left to its own fate (Essetti, 1999) and suffered gradual degradation until it fell into ruin. In 1992, it was declared a National Historical Monument, and in the first decade of the 21 th century, restoration works were carried out as a result of an international cooperation between Spain and Tunisia. The institution responsible for this property is the Ministry of Culture and Heritage Conservation of Tunisia.

The presence of archaeological material from Roman times dating back to the 1st and 2nd centuries A.D. on the island is also noteworthy, as it includes an opus africanum structure and a polychrome mosaic with geometric floral motifs and epigraphs written in Latin. Remains of the Byzantine era dating back from the 5th and 6th century A.D. have also been found.

The landscape potential of this island is one of its greatest attractions, as there are good visibility conditions from the tower of the fort that also offer high-quality panoramic views stretching $20 \mathrm{~km}$ towards the city of Tunis, the National Park, Jbel Bou Kornine National Park, Jbel Ennahli Park, the town of Sidi Bou Said, Gammarth, Rades Harbour and La Goulette (Martínez-Sanchís, 2015).

The island and the fort have never been subject to regular and organized visits, and there is no legal regulation of public visitation, even though the island has a guard in the daytime and another at night to prevent plundering and looting. Since the completion of 
the restoration works in 2010, the possibility of legal regulation has been raised. The first consequent analysis addressed its recreational carrying capacity.

Regarding facilities, the island is ringed by a circular path of $850 \mathrm{~m}$ with an average width of 2 to $3 \mathrm{~m}$. There is a small pier where rowboats or small motorboats can dock.

Specific issues have been detected in the definition and management of the recreational carrying capacity of this island, which are related primarily to the island and fort's different resistance and fragility. Indeed, the island is highly ecologically vulnerable due to the presence of nesting species of high regional value, and from March to mid-July, must remain closed to visitation for conservation reasons. The island also presents a high landscape fragility due to the existence of multiple viewpoints, as it is flat and surrounded by a circular path and also offers viewpoints on raised platforms, such as the tower of the fort. The presence of humans thus becomes a visual intrusion that affects the integrity of the landscape (fig. 5). Moreover, as the fort is centrally located, it obstructs the midplane of some viewsheds, though not in a way that can permanently hide visitors, as the established angle of each viewshed is approximately $120^{\circ}$, which is the same as the human field of vision (fig. 6).

However, Fort Santiago is a resistant space and offers many large spaces in which to comfortably receive visitors considering wide spatial standards and avoiding encounters with other groups. Transit areas are located on the ground floor, around the courtyard, which has a fully usable surface of $607.2 \mathrm{~m}^{2}$, with six rooms of approximately $8 \mathrm{~m}^{2}$ each that are open to visitors. Moreover, there is a terrace on the top floor of $292.1 \mathrm{~m}^{2}$ that is used as a circulation area and a tower for observation of the lagoon landscape with a surface area of $17.4 \mathrm{~m}^{2}$.

Transportation is also a major limiting factor. Despite its proximity to the coast (2 $\mathrm{km})$, the shallow lagoon waters (1 $\mathrm{m}$ deep) and the birds flying over them, boats cannot

\section{Figure 5 \\ LANDSCAPE FRAGILITY ON CHIKLY ISLAND, WHERE THE VISITORS REPRESENT A VISUAL INTRUSION}

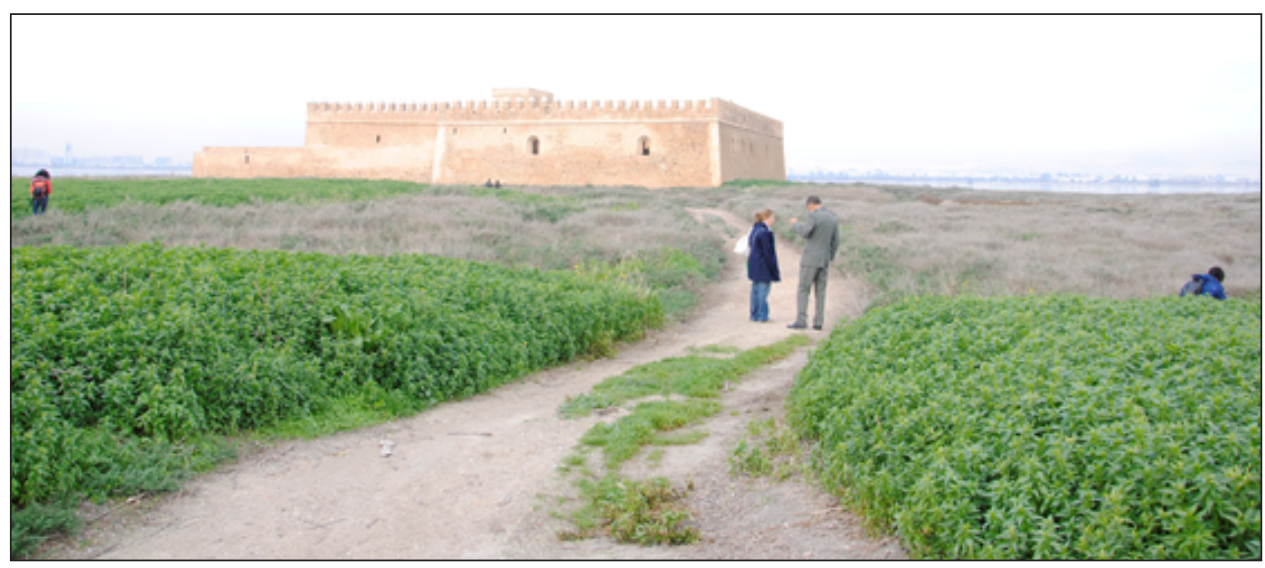




\section{Figure 6 \\ VIEWSHEDS FROM THE VIEWPOINTS OVERLOOKING THE CIRCULAR PATH OF CHIKLY ISLAND (ROMAN RUINS, SALT MARSHES) CONDITIONED BY THE PRESENCE OF FORT SANTIAGO. THE EYE ICONS REPRESENT THE VIEWPOINTS, AND THE AREAS VISIBLE ARE HIGHLIGHTED}
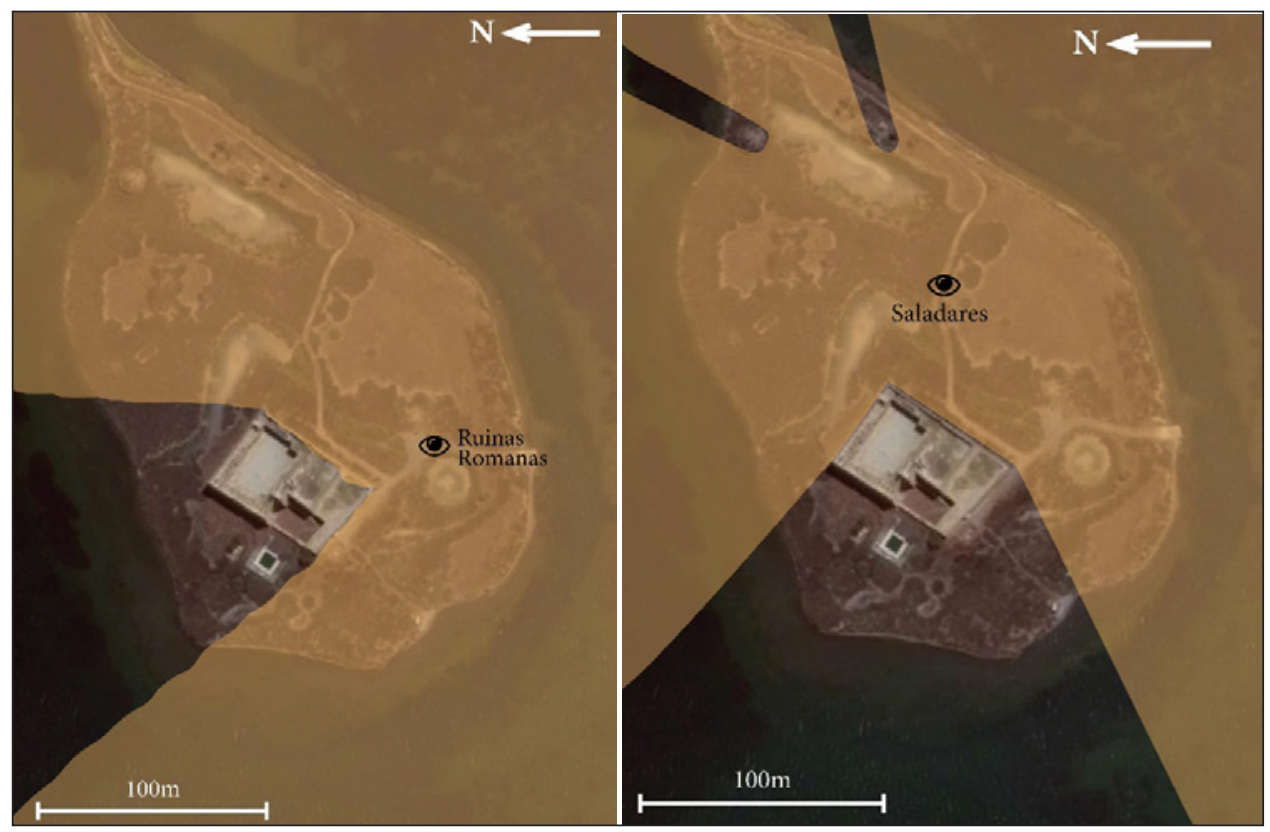

be large $(<6.5 \mathrm{~m})$ or noisy, and there is only one departure harbour on the shores of the lagoon at the Nautical Club, so access to the island is quite restricted.

Given the intrinsic ecological fragility of the island, its small size and flat morphology that make it visually vulnerable and the difficult transport conditions, the presence of more than 20 people on the island is not recommended. It is always necessary to divide visitors into two groups (10 in the fort and 10 on the island), as the staff of the Nature Reserve cannot control a larger group in such a fragile place, where nests are close to the path. Thus, a quality experience can be offered to visitors. The daily quota of visitors has not been established, but it is assumed that it cannot be high for the reasons described above.

\subsection{S'Espalmador Island}

$S^{\prime}$ Espalmador Island $\left(38^{\circ} 47^{\prime} \mathrm{N}\right.$ and $\left.1^{\circ} 25^{\prime} \mathrm{E}\right)$ is one of the Pityusic Islands belonging to the Archipelago of the Balearic Islands (Spain). It covers $1.38 \mathrm{~km}^{2}$ and is separated by only approximately 300 metres from the sandy peninsula d'Es Trucadors, where Ses Illetes, the most popular beaches in Formentera, are located. These beaches attracted 287,000 people 
between May and September 2015, according to the data provided by the Island Council of Formentera (Consell Insular de Formentera), the General Directorate of Sustainability of the Coast and the Sea (Dirección General de Sostenibilidad de la Costa y del Mar), and the Ministry of Agriculture, Food and Environment -MAGRAMA-. This channel has very shallow waters that is connected to the mentioned peninsula by a sandy strip that is a submerged prolongation of the mentioned peninsula.

S'Espalmador is part of the Natura 2000 network in the Special Area of Conservation (SAC) of Ses Salines d'Eivissa i Formentera. It is designated a Site of Community Importance (SCI) and Special Protection Area (SPA) and falls into various categories of protected areas, including Natural Park of Ses Salines d'Eivissa i Formentera (Law 17/2001 of 19 December) and Nature Reserve of Ses Salines of Ibiza, Freus Islands and Salines of Formentera (Decree 63/1999 of 28 May). Furthermore, since 1993, Ses Salines d'Eivissa i Formentera have been included on the List of Wetlands of International Importance, as defined by the Ramsar Convention, and its marine habitat of seagrass (Posidonia oceanica) meadows was declared a World Heritage Site by UNESCO in 1999. The island is sporadically inhabited and is privately owned but accessible to the public.

Geostructurally, the Pityusic Islands (Ibiza, Formentera and some islets such as S'Espalmador or S'Espardell) are mountainous remnants of Mesozoic materials of the Prebaetic System covered by Tertiary and Quaternary sediments and slightly tilted to the east. Thus, the western coasts form small cliffs 15 metres high (Servera, 1999), except at Cala of S'Alga to the south and Sa Torreta to the north, which are natural refuges for boats. Dune fields can be found along these coastal areas. Inland, there are slight land elevations such as Pujol d'en Garrigó and a small muddy pond lagoon known as S'Estanyol (fig. 7).

As in previous cases, the climate is typically Mediterranean. This is one of the Balearic Islands with the lowest rainfall ( $370 \mathrm{~mm}$ per year, mainly in spring and autumn) and highest temperatures (an average annual temperature of approximately $18^{\circ} \mathrm{C}$ ). The most characteristic climatic feature is the wind blowing from the northwest towards the northeast in winter and from the south towards the southeast in summer; the Levant (east) is the dominant wind, blowing on $21 \%$ of days (AAVV, 2012).

The biodiversity of S'Espalmador includes 265 catalogued species, mostly shared with the nearby island of Formentera. Moreover, there are more than 30 endemic species (shared with the whole of the Pityusic and the Balearic Islands in many cases).

The flora is of exceptional rarity and biogeographical value. There are 11 endemic or sub-endemic taxa, including hedge mustard (Diplotaxis ibicensis), 2 evergreens (Limonium ebusitanum and Limonium scorpioides), one campion endemic to these islands and to the east coast of Spain (Silene cambessedesii) and one linaceae endemic to the Pityusic Islands and Majorca (Chaenorrhinum formenterae). There are other taxa distributed only in the south that are present only on the Pityusic Islands, such as Lotus halophilus, Lotus creticus, Cynomorium coccineum and Linaria pedunculata. In the flooded areas of S'Estanyol, the sedum community is dominated by samphire (Sarcocornia fruticosa). Farther inland, the dominant vegetation is savin woods, both on dunes and rocks.

The animal community is known by its endemic components, including some groups of invertebrates such as beetles, especially darkling beetles, of which 19 endemic forms were found. An endemic reptile, the Pitiusan wall lizard, is also significant, with the subspecies 
Podarcis pityusensis formenterae being found on Formentera and S'Espalmador. Birds, particularly sea birds, such as pelagic and coastal birds, are the most widely represented group. The latter include the yellow-legged gull (Larus michaelis) and Audouin's gull (Larus audouinii). However, pelagic birds are of greater interest, including Cory's shearwater (Calonectris diomedea), the European storm petrel (Hydrobates pelagicus) and an endemic species of the Balearic Islands: the Balearic shearwater (Puffinus mauretanicus), which nests on S'Espalmador and is classified as a critically endangered species.

\section{Figure 7}

\section{FACILITIES AND MAIN ATTRACTIONS ON THE ISLAND OF S'ESPALMADOR}

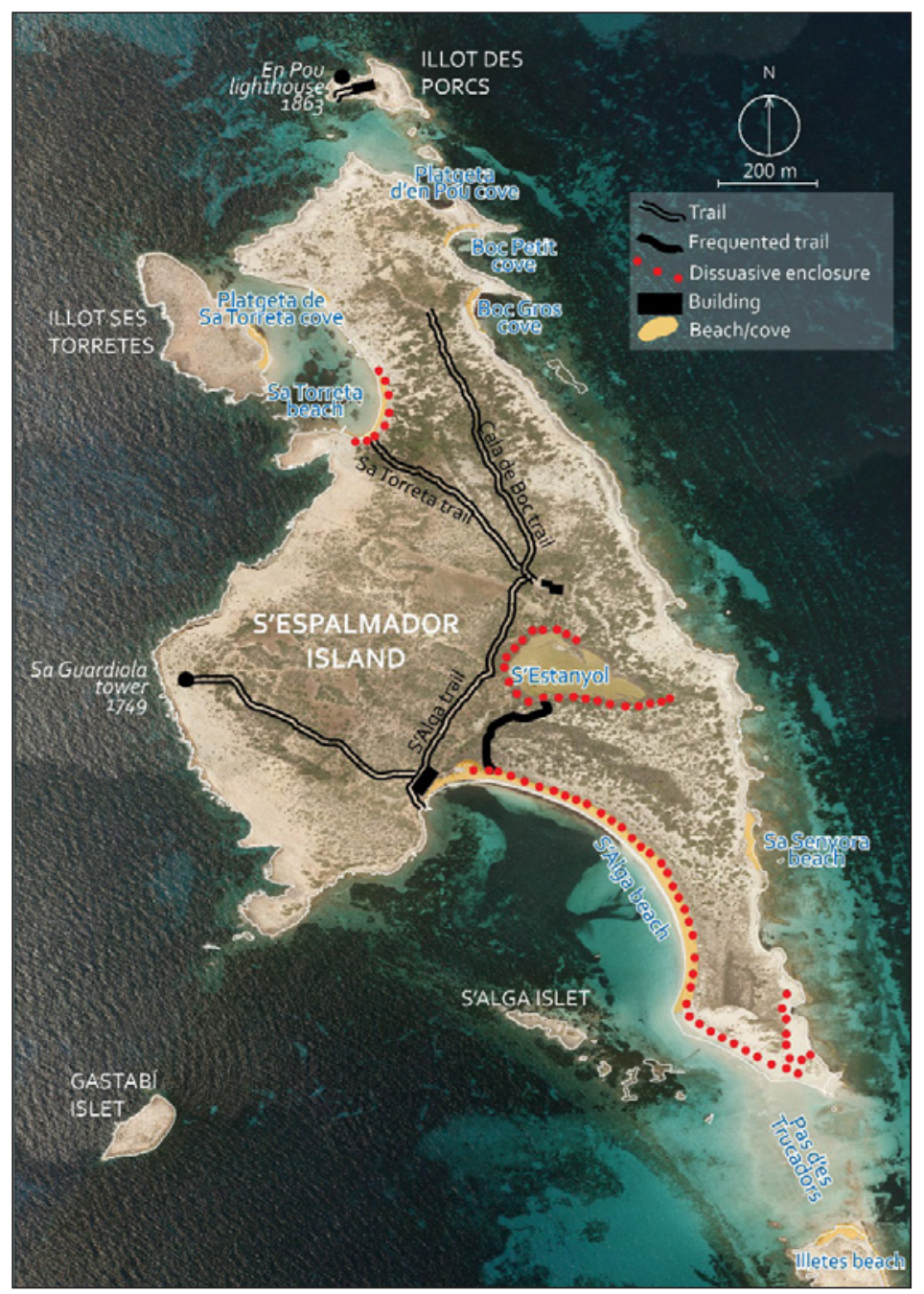


Regarding historical facts, there is evidence of a Punic settlement from the 3rd to the 1st centuries B.C., as well as evidence of a Roman villa. Later, in the 16th and 17th centuries, island was used as a refuge for pirates who devastated the Mediterranean Spanish coasts. In 1749, the watchtower of Sa Guardiola was constructed (Consell Insular de Formentera, 2001). In the 19th century, a traditional house (Can Vidal) was built, and a family inhabited the island on a regular basis. Various agricultural and extractive exploitations (pedra tosca) as well as fisheries are recorded. In the 20th century, the island was a refuge for smugglers, and other houses were built on S'Alga by the owners of the island.

Recreational facilities on S'Espalmador are scarce: there is a path leading from the beach of S'Alga to S'Estanyol, with a length of $325 \mathrm{~m}$ and an average width of $1.5 \mathrm{~m}$, and other small paths that link the tower of Sa Guardiola to the coves on the north of the island (fig. 7).

Figure 8

VISITORS LANDING FROM A COMMERCIAL CATAMARAN ON THE SOUTHERN PART OF THE BEACH OF S'ALGA, NEAR PAS D'ES TRUCADORS. PICTURE TAKEN AT NOON IN AUGUST 2015

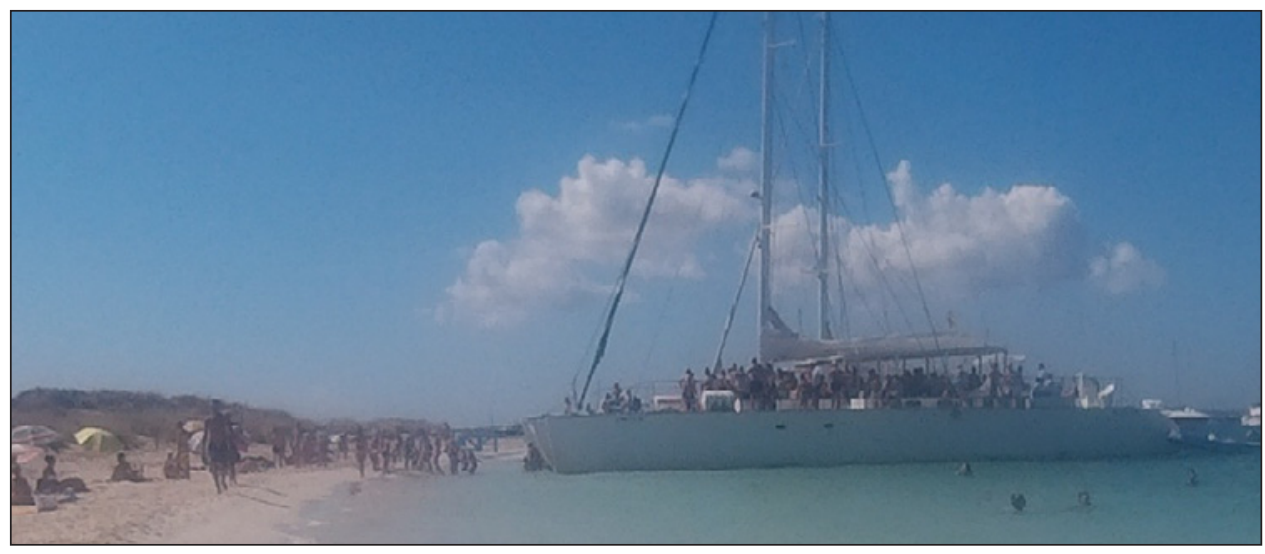

The island is easily accessible by boat, swimming and even by foot (at low tide, the water does not exceed 1.5 meter deep), as the distance between S'Espalmador and Ses Illetes on Formentera can be overcome by wading across Pas d'Es Trucadors. Still, the island is mainly accessed by boats departing from La Savina Harbour (Formentera). A catamaran company offers organized cruises for groups, and two others carry individual passengers; both companies operate with permission from the General Directorate of Sustainability of the Coast and the Seas (MAGRAMA) (fig. 8). Visitors travel to the island for the quality of its beaches and its landscapes. The most popular beach is S'Alga, with a length of $870 \mathrm{~m}$ and an average width of $14 \mathrm{~m}$. The northern coves of Sa Torreta, Boc Gran and Boc Petit can be reached by boat. 
Visits are regulated by the Master Plan for the Use and Management (PRUG) of the Natural Park of Ses Salines de Eivissa i Formentera (Decree 132/2005 of the Government of the Balearic Islands). Thus, in the section on protected natural area management standards, Article 102 includes among the «incompatible activities» walking on dune systems or habitats of interest outside of designated pathways. On beaches with developed dune systems, a deterrent lightweight enclosure supports the provisions of Chapter 5, «Tourism and recreational activities» of Title VIII, «Uses and Activities». Similarly, Article 12, «Area Regulations» in Section II, paragraph 5 of prohibited uses, prohibits «Bathing and using mud from the pond of S'Espalmador» (key APE-02). Nevertheless, it is common to see visitors of the island invade the lagoon and take mud baths, despite prohibitive signs. This activity, together with other visitor behaviours, shows that they do not consider the pond to be a protected area. There is thus a need to develop awareness programs to mitigate such behaviours (AlonsoMonasterio, 2014).

In addition to the island's visitors, many private and rented pleasure boats are also registered in its surrounding waters, moored in the bay of S'Alga. Thus, the number of ecological mooring buoys has progressively increased in summer, and in 2015, there were 51 buoys for boats of up to $25 \mathrm{~m}$ long. A greater number is allowed in the Master Plan for the Use and Management (70 buoys, section 4.1.6.a of the action lines of the Plan, on the management of water activities). In 2014, according to the information provided by the Department of Agriculture, Environment and Territory of the Balearic Government, 1,787 boats were registered at S'Espalmador. Authorized visitor landing is described in section «a» of Article 105 «Authorised activities» of Title III: « $i$. The use of mooring points is only allowed to oficial agencies, for emergency and monitoring reasons. Visitors landing is allowed if coming in authorised boats by the Regional Environmental Authority. These visits must have educational and awareness

\section{Figure 9}

VIEWSHEDS OF S'ESPALMADOR (PATH TO S'ESTANYOL, S'ESTANYOL BEACH, AND NORTH OF S'ALGA BEACH). NOTE THAT THE PANORAMIC SEA VIEWS ARE BROADER. THE EYE ICONS REPRESENT THE VIEWPOINTS, AND THE AREAS VISIBLE FROM THOSE VIEWPOINTS ARE HIGHLIGHTED
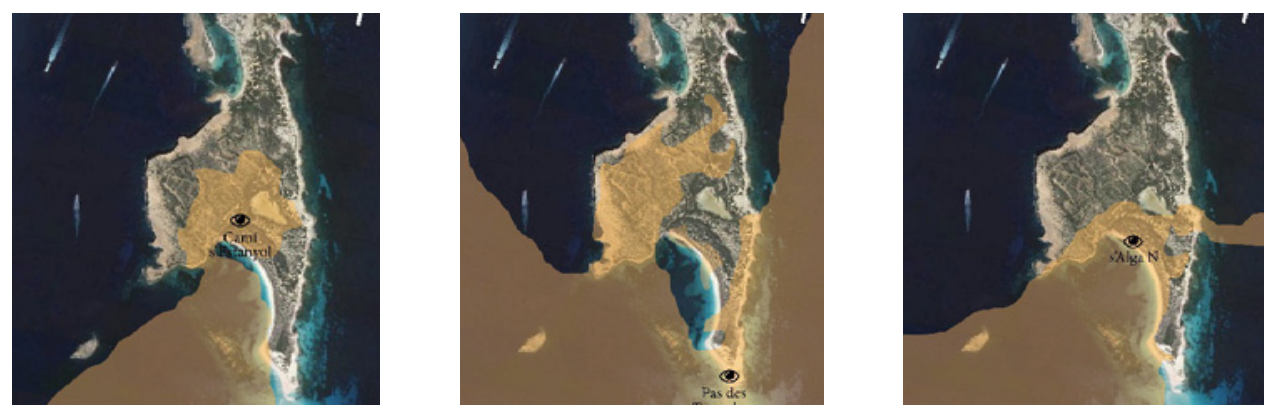
purposes to be authorised» and in paragraph «e», «e) on S'Espalmador Island, only the deployment of buoy fields as provided for in the action lines of this Master Plan is authorised, as well as beached boats which have been authorised by the Managing Board of the natural protected areas, if these visitor transportation services AVE guided tours with educational purposes.»

When estimating the recreational carrying capacity of this island, the primary determining factors, as in the previous cases, are related to the high number of endemic animal and plant species and to the fact that critically endangered species nest there.

In relation to the landscape fragility, the morphology of the island, with its elevations and depressions, and the presence of plants of a certain size mitigate the visual impacts of visitors in some places to a slight degree (fig. 9).

The most significant factor is the congestion of visitors on S'Alga beach and of boats in the adjacent bay, given the ease of access to this island. Thus, after considering at least $1 \%$ of the estimated 287,000 bathers who visited Ses Illetes between May and September 2015 as potential visitors to S'Espalmador (crossing the shallow channel via swimming or walking) and considering the visitors who arrived via sailboat, motorboat or small inflatable boat as well as those passengers carried by authorized tour companies, the figures obtained represent a significant threat. With such a mass of people concentrated in a narrow strip, the expectation of the exclusive feeling of a small island is lost. Over time, this fact will jeopardize its attractiveness to tourists; however, the greatest danger to its attractiveness is uncontrolled use, exceeding resource thresholds.

In addition, the presence of too many boats moored in bays disrupts sea panoramas, especially at sunset, through intrusion and visual obstruction. Given the importance of sunsets as a tourism resource on these islands, this obstruction should be noted.

Furthermore, there is a lack of access control to the island and its adjacent environment. This fact is related to the site management practices, as no daily visitor quota has been established (with regard to recreational carrying capacity). As was already mentioned, although this island is very close to other inhabited islands and access is free and easy by sea and by foot and although the island is a protected area with legislation providing for restrictions in this regard, there is no control of traffic through the interior of the island beyond lightweight deterrent enclosures.

Neither is there tight control on traffic or moored boats, and a reduction in the number of permitted mooring buoys should be considered, as all studies point to a substantial loss of the Posidonia seagrass meadows in recent years (Oceansnell, 2012; GEN, 2014). The number of daily passengers on commercial cruises could also be reduced, and visits should be more strictly regulated (organized, scheduled, guided tours, etc.), as indicated in the Master Plan for Use and Management of the Natural Park. Action is being taken to discourage foot traffic through the shallow water channel in the form of a Warning sing posting and a red flag intended to inform bathers about the dangers of this decision. Moreover, the local government provides two lifeguards with jet skis in summer to reduce personal risks. In addition to warning notices to swimmers about possible dangers, it is advisable to raise awareness about environmental impacts caused by visitor saturation and congestion to prevent undesirable behaviours because visitors to S'Espalmador do not currently seem to perceive it as a natural protected area. 


\section{DISCUSSION AND CONCLUSIONS}

After studying the intrinsic characteristics of island ecosystems and analysing case studies, various points emerged regarding recreational carrying capacity determination and management, which is a technical tool with great value in ensuring resources conservation and providing a quality experience for visitors.

First, it should be noted that in the assessment of natural resources, the ecological component has greater weight in these ecosystems than in others. In addition to the information provided by the scientific literature, all of the analysed case studies demonstrate that the number of endemic species, the type of species, and being nesting sites give smaller islands high intrinsic ecosystem fragility, while their small size makes zoning unworkable. In terms of analysis of the recreational carrying capacity, these are clear cases in which resources are not only a tourist attraction (fauna, flora, geological and geomorphological settings) but also the physical support (soils, sediments, and seabeds) of the recreational activities that take place there. The islands also receive the wastes generated by visitors. Thus, tourism activites demand the highest performance on very vulnerable resources that can sometimes be irreversibly damaged, as observed in the Columbretes Islands, where reptiles have gone extinct because of arson.

Even though, small islands have very restrictive forms of protection, resource conservation is not totally guaranteed because, as illustrated on S'Espalmador, the current legislation is often not enforced because of a lack of material and human resources and a lack of coordination among administrations, among other factors. At other times, temporary restrictions on visits or closures are regularly implemented at crucial moments of wildlife cycles (breeding and nesting or to allow vegetation to recover).

The island landscape analysis has yielded interesting conclusions regarding their fragility. As these are small islands, viewsheds, which are usually framed by the viewing angle of the human eye, are highly vulnerable due to visitor intrusion or obstruction. Hence, in the case studies, recommendations were made concerning the organization of visits (distribution of groups) to allow visitors to enjoy quality panoramic views. The case of quality of the panoramic sea views is difficult to solve as long as boat moorings are not more restrictively regulated, as on S'Espalmador.

In relation to facilities, on islands where heritage assets can be visited, besides being important tourism attractions, they are appropriate places to organize visits and better manage the recreational carrying capacity, allowing handling of a higher number of people at one time (PAOT). Indeed, they usually have a higher recreational carrying capacity than the island itself, as is the case for Fort Santiago on Chikly Island and the lighthouse on the Columbretes Islands.

Circular paths also assist in organizing visits and avoiding encounters with other groups, although it is not always possible to design these paths because of the morphology of the island and the location of vulnerable elements.

Moreover, there are no accurate data on the number of visitors. It seems that on the Columbretes Islands, the established limits are generally not exceeded, whereas S'Espalmador shows clear symptoms of congestion in S'Alga Bay during the summer months, and although no precise data in that regard are available, very high figures are 
assumed. Thus, proximity to the mainland or to other inhabited islands favours visits due to the reduced travel time, the lower cost of transport, and psychological factors related to the visitors' safety, ensuring that the effort-reward balance is favourable.

No sociodemographic data or data on visitor personality traits are available, so it was not possible to examine their psychological comfort needs. However, according to the observed activities that they develop, it can be suggest that visitors to the Columbretes Islands mainly seek «educational and interpretative» activities and secondarily seek «leisure and entertainment», in contrast to S'Espalmador, where hedonistic activities (sunbathing and sea) prevail. Activities on Chikly Island are designed for an «educationalinterpretive» public.

Finally, it should be highlighted that the key to managing the carrying capacity of an island is controlling the means of transportation. Reigner et al. (2012) already established this point in regard to terrestrial protected areas, but it is even more significant for islands because most visitors access them using commercial cruises offering regular service. The case of accessing S'Espalmador on foot is a special situation that must be regulated. It would be appropriate to reinforce awareness among visitors regarding the dangers of this crossing. They should also be reminded about the emotional dissatisfaction that arises from arriving in a crowded place when an effort was made to enjoy a unique experience.

\section{BIBLIOGRAPHY}

ALONSO-MONASTERIO, P. (2014): Análisis de la eficiencia comunicativa y las funciones interpretativas de los mapas turísticos para la visita de espacios con patrimonio. PhD dissertation. Departamento de Ingeniería Cartográfica, Geodesia y Fotogrametría, Universitat Politècnica de València.

AMADOR, E.; CAYOT, L.; CIFUENTES, M.; CRUZ, E. and CRUZ, F. (1996): Determinación de la capacidad de carga turística en los sitios de visita del Parque Nacional Galápagos. Servicio Parque Nacional Galápagos e Instituto Ecuatoriano Forestal y de Áreas Naturales y Vida Silvestre. Puerto Ayora. Ecuador.

AAVV (2012): Enciclopèdia d'Eivissa i Formentera, versió web. Available in http://www. eeif.es/significados/e-volum\%20V/Espalmador.html. Last consulted: 14/11/2015

BANQUE MONDIALE (2011): Adaptation au changement climatique et aux désastres naturels des villes côtières d'Afrique du nord. $342 \mathrm{pp}$.

BERNARDA, L.A. and LEWIS, G. (2003): «Informal work and common mental disorders». Social Psychiatry and Psychiatric Epidemiology, no 38 (9), 485-489.

BOWETT, D.W. (1979): The legal regime of islands in international law. New York: Oceana Publications.

BUCKLEY, R. (2002): «Surf tourism and sustainable development in indo-pacific islands. II Recreational capacity management and case study», Journal of sustainable tourism, Vol 10. No. 5: 425-442

CABILDO DE LANZAROTE (2013): Estudio de capacidad de carga cabildo de Lanzarote -Plan Insular de Ordenación de Lanzarote. Documento Técnico, 39 pp.

CHASQUI, L. (2008): Capacidad de Carga Turística del Parque Nacional Isla del Coco. PNUD, Costa Rica. 2008. 62 pp. 
COLE, D. and CARLSON, TH. (2010): Numerical Visitor Capacity: A Guide to Its Use in Wilderness. United States Department of Agriculture / Forest Service Rocky Mountain Research Station General Technical Report RMRS-GTR-247

CONSELL INSULAR DE FORMENTERA (2001). El patrimoni cultural de Formentera. DAVIDSON, J. (Ed.) (2003): Phobic geographies. The phenomenology and spatiality of identity. Ashgate Publishing Co. (Burlington, USA).

DEL HOYO, J. (Ed.) (1992): Espais Naturals. Història Natural dels Països Catalans, $n^{\circ}$ 15. Ed. Barcelona, Fundació Enciclòpedia Catalana.

ERENA, S.L. (2014): Espacio marino de Illes Columbretes. Proyecto LIFE + INDEMARES. Ed. Fundación Biodiversidad del Ministerio de Agricultura, Alimentación y Medio Ambiente.

ESSETTI I. (1999): L'ilot de Chekly, patrimoine naturel et historique. Centre d'Activités Régionales pour les Aires Spécialement Protégées (CAR/ASP).Tunis.

FIGUEROA, E. and ROTAROU, E.S. (2013): «Impactos ambientales y desafíos del desarrollo turístico en Isla de Pascua». Gran Tour: Revista de Investigaciones Turísticas, $\mathrm{n}^{\circ}$ 7, pp. 39-59.

FONT TULLOT, I. (1984): Atlas de la radiación solar en España. Instituto Nacional de Meteorología, 88 pp.

GEN (2014): La Posidonia, una responsabilidad compartida Seguimiento de zonas de fondeo (Eivissa, 2014). Unpublished report, available in http://www.gengob. org/docs/posidonia-una-responsabilidad-compartida-2014.pdf. Last consulted: 03/02/2016.

GÓMEZ MARTÍN, B. (1999): «La relación clima-turismo: consideraciones básicas en los fundamentos teóricos y prácticos». Investigaciones Geográficas, 21, pp. 21-34.

GUENCHI, S. and ROSELL, M. (2010): Capacidad de carga turística de un sector de la Reserva Natural de Uso Múltiple Isla de Puan, Argentina. Nadir: Revista Electrónica Geografia Austral, ${ }^{\circ} 2$.

HALL, T. (1966): The Hidden Dimension. Anchor Books, New York.

HAM, S. (1992): Environmental Interpretation. A practical guide for people with big ideas and small budgets. Golden, Colorado, USA: Fulcrum Publishing. 456 pág.

HERNÁNDEZ, M.L. (1990): Frecuencia e intensidad del viento en Zaragoza. Geographicalia, 27, pp. 63-75.

INICIATIVA PIM, Available in: http://www.initiative-pim.org/en/presentation, Last consulted: 11/11/2015.

JACKSON, I. (1986): «Carrying capacity for tourism in small tropical Caribbean islands». Industry and Environment, vol. 9, $\mathrm{n}^{\circ}$ 1, pp 7-10.

LEPP, A. and GIBSON, H. (2003): «Tourist roles, perceived risk and international tourism». Annals of Tourism Research, $\mathrm{n}^{\circ}$ 30, 606-624.

LINE, N. and COSTEN, W. (2011): Environmental attitudes, motivation, and attachment: Toward a model of nature-based tourism. International CHRIE Conference-Refereed Track. Paper 5.

LUO, Y. and DENG, J. (2008). «The new environmental paradigm and nature-based tourism motivation». Journal of Travel Research, $\mathrm{n}^{\circ}$ 46, 392-402. 
MACHADO, A. (2010): «Principales problemas que afectan específicamente a la biodiversidad en islas»,Ambient@, 91. Available in: www.revistaambienta.es/ WebAmbienta/marm.

MANNING, R. (2011): Studies in Outdoor recreation: Search and Research for Satisfaction. 3rd ed. Corvallis: Oregon State University Press.

MANNING, R., FREIMUND, W., LIME, D. and PITT, D. (1996): Crowding norms at frontcountry: A visual approach to setting standards of quality. Leisure Sciences, 18, pp. 39-59.

MANNING, R. (1999): Studies in Outdoor Recreation . Corvallis: Oregon State University.

MARTÍNEZ IBARRA, E. (2006): Consideraciones geográficas en torno al binomio clima- turismo: aplicación al litoral alicantino. $\mathrm{PhD}$ dissertation. Universitat d'Alacant

MARTÍNEZ-SANCHIS, I. (2015): Propuesta para la puesta en valor del Fuerte español de Santiago (s. XVI) en la Isla de Chikly, Túnez. MSc dissertation. Universitat Politècnica de València (Unpublished).

MATA, R. (2006): «Desarrollo sostenible, insularidad y gobierno del territorio: la experiencia del PTI de Menorca». Boletín de la Asociación de Geógrafos Españoles, $\mathrm{n}^{\circ} 41$, pp. 183-198.

MAUFRET,A.; MONTADERT, L.; LAVERGNE, M.; and WILLM, C. (1978): «Geological and geophysical setting of DSDP site 372 (Western Meditrranean)». Drilling Project, vol.42, part.1, pp. 889-897.

MORANT, M. and VIÑALS, M.J. (2010): «Modelo para evaluar la capacidad de carga recreativa en áreas de uso público intensivo de espacios protegidos. Casos de estudio de la Comunidad Valenciana (España)», in Turismo y gestión de espacios protegidos. Valencia, Tirant lo Blanc, pp. 620-636.

MORGAN, D.J. and LOK, L. (2000): «Assessment of a Comfort Indicator for Natural Tourist Attractions: The Case of Visitors to Hanging Rock, Victoria». Journal of Sustainable Tourism, 8 (5), pp. 393-408.

NEFFATI, M.; GHRABI, N.; AKRIMI, N. and HENCHI, B. (1999): «Les plantes endémiques de la Tunisie», in Flora Mediterrànea, no 9, pp. 163-174.

OCEANSNELL (2012): Evaluación del impacto del fondeo de embarcaciones sobre las praderas de Posidonia oceánica en el norte de Formentera (Baleares). Unpublished report, available in: http://oceana.org/sites/default/files/OCEANA_121219_ INFORME_Resultados_P12-007_Rev.1_.pdf. Last consulted: 03/02/2016.

PASCUAL GUASCH, R. (1975): «El pecio de Columbretes», Cuadernos de Prehistoria y Arqueología Castellonenses, $\mathrm{n}^{\circ} 2, \mathrm{pp} .185-190$.

PAUTOT, G.; AUZENDE, J.M. and OLIVET, J.L. (1973): «Valencia Basin». Drilling Project, vol.13, part.2, pp.1.430-1.441.

PRIMACK, R.B. and ROS, J. (2002): Introducción a la biología de la conservación. Ariel Ciencia. Barcelona. RAMSAR (2013): Available in: http://www.ramsar.org/doc/ ris/key_ris_f.doc

REIGNER, N.; KISER, B.; LAWSON, S . and MANNING, R. (2012): Using transportation to Manage Recreation Carrying Capacity. The George Wright Forum, vol. 29, no 3 , pp. 322-337. 
ROIG MUNAR, F.J. (2003): «Análisis de la relación entre la capacidad de carga física y capacidad de carga perceptual en playas naturales de la Isla de Menorca». Investigaciones Geográficas, $\mathrm{n}^{\circ} 31$, pp. 107-118.

SCHRAMM, W. (1965): «How communication works». In W. Schramm, The process and effects of mass communication (págs. 3-26). Urbana, Illinois: University of Illinois Press.

SEGRADO, R.; PALAFOX, A. and ARROYO, L. (2008): «Medición de la capacidad de carga turística de Cozumel». El Periplo Sustentable, nº13, pp. 33-61.

SERVERA, J. (1999): Principals trets fisiogràfics i climàtics de les Pitiüses, Territoris, $\mathrm{n}^{\circ}$ 2, pp. 9-37.

SHAFFER, M.L. (1998): «Minimum population sizes for species conservation», Bioscience, vol. 31 (2), 131-134.

STANKEY, G. and McCOOL, S. (1984): Carrying capacity in recreational settings: evolution, appraisal, and application. Leisure Sciences, vol. 6, pp. 453-473.

STANKEY, G., COLE, D., LUCAS, R., PETERSEN, M. and FRISELL, S. (1985): The limits of Acceptable Change System for Wilderness Planning. General Technical Report INT-176. Ogden, UT: US Department of Agriculture-Forest Service, Intermountain Research Station.

TELlADO, V., PIORNO, V. and FERNÁNDEZ, J.A. (2014): Gestión y estrategias aplicadas a la conservación y el desarrollo del Parque Nacional de las Islas Atlánticas de Galicia. Revista Científica Monfragüe desarrollo resiliente. Vol. III, nº 2, pp. 72-87.

TRAPP, S., GROSS, M. and ZIMMERMAN, R. (1994): Signs, Trails, and Wayside Exhibits: Connecting People and Places. Stevens Point, Wisconsin, USA: University of Wisconsin-Stevens Point Foundation Press.

VAN DER BORG, J. (2001): Tourism Development, Carrying Capacity and Historical Settlements. Paper presented to the Workshop «Defining, Measuring and Evaluating Carrying Capacity in European Tourism Destinations», Athens 10/9/2001.

VAN TILBURG, M.L. and VINGERHOETS, J.J.M. (Eds.) (2005): Psychological Aspects of Geographical Moves. Homesickness and Acculturation Stress. University Press (Amsterdam).

VASKE, J.J. and DONNELLY, M.P. (2002): Generalizing the encounter-norm-crowding relationship. Leisure Sciences, vol. 24, pp. 255-269.

VELASCO, R. (2013): Capacidad de carga Isla La Roqueta, Acapulco, Gro., México. . http://www.academia.edu/7223282/Capacidad_de_carga_Isla_La_Roqueta_Acapulco_ Gro._M\%C3\%A9xico. Last consulted: 15/12/2015.

VIÑALS, M.J.; ALONSO-MONASTERIO, P. and ALONSO-MONASTERIO, M. (2013): «Analysis of the Spatial Standards and Perceptual Components of the Recreational Carrying Capacity Applied to Archaeological Sites: Case Study of Castellet de Bernabé (Llíria, Spain)». In: Mondéjar, Vargas Ortega y Perez Calderon (Eds.): Methods and Analysis on Tourism and Environment. Ed. Nova Science Publishers (New York), pp. 109-120.

VIÑALS, M.J., MORANT, M. and TERUEL, L. (2014): «Confort psicológico y experiencia turística. Casos de estudio de espacios naturales protegidos de la Comunidad Valenciana (España)». Boletín de la Asociación de Geógrafos Españoles, nº 65, pp. 293-316. 
VIVAS, G.F. (2009): «El espacio público como parte del sistema de lugares en tres casos de estudio». Fermentum, no 54, pp.11-34.

WESTRA, L., GRAY, J. and KARAGEORGOU, V. (2015): Ecological Systems Integrity: Governance, Law and Human Rights. Ed. Routledge, 306 pp.

WHITTAKER, R.J. and FERNÁNDEZ-PALACIOS, J.M. (2007): Island biogeography. Ecology, evolution and conservation. Oxford, Oxford University Press.

WORLD TOURISM ORGANIZATION (2004): Tourism Congestion Management at Natural and Cultural Sites. UNTWO (Madrid).

ZUCKERMAN, M. (2007): Sensation seeking and risky behavior. American Psychological Association (Washington D.C.). 
